\title{
Bilingual Dictionaries of the Turkic People as Indicator of Identity of Cultures
}

\author{
Alfiya Shavketovna Yusupova \\ Elvira Nikolaevna Denmukhametova
}

Kazan (Volga) Federal University, Russia, Kazan, Kremlevskaya St., 18a

\author{
Doi:10.5901/mjss.2015.v6n6s2p87
}

\begin{abstract}
For acquaintance to the people, its traditions and mentality, first, it is necessary to know its language. Through comparisons of linguistic designs of the native and learned language it is possible to draw parallels, to reveal specifics of thinking and to make overall picture of the world of the people talked in this language to learn its identity. The first assistant, in this case, certainly, are translation dictionaries. In article questions of the emergence of bilingual dictionaries of the Turkic people, their structure, social and cultural functions as translation dictionaries is the major practical grant when studying other language are considered. The aim of this paper is to throw light upon the structure of bilingual dictionaries of Turkic peoples (including Tatar dictionaries) and their first publishing. Due to the changes of peoples' view to the life and their attitudes towards these changes dictionaries reflect the changes of an active vocabulary of languages. In work development of the Tatar bilingual dictionaries (especially Tatar-Russian and Russian-Tatar lexicographic sources), as one of representatives of the Turkic world is in detail investigated; the structure, methods and methods of drawing up dictionaries are reflected, the analysis is given to dictionary entries, reflecting identity and mentality of the Turkic people. The presented material is the first experience of illumination of mental qualities of the Turkic people, including the Tatar people recorded in the form of lexemes in bilingual dictionaries. They give an objective assessment of mastering of the user of sociocultural competence, reflected in lexicographic sources. Results of this research assist active use of bilingual dictionaries in studying of Turkic languages for the purpose of diagnostics of levels of proficiency as language, and identification by information on the identity of the Turkic people.
\end{abstract}

Keywords: language, dictionaries, Turkic people, Tatar language, identity.

\section{Introduction}

Language dictionaries carry out important social and cultural functions. On the one hand, they help representatives of the different people to know and understand better each other, to solve in common vital problems. On the contrary, such dictionaries concentrate in themselves the bulk of the knowledge accumulated by the time of their creation at these or those people and society. Throughout the previous centuries, hundreds of bilingual dictionaries have been created. In them various systems of construction and interpretation of the material, in some more successful, in others - are used less. Bilingual, or translated, the dictionary is the major practical grant when studying another language. At the same time, it is result of linguistic researches of his originator as in the course of the lexicographic description of any concrete language it often faces problems which successful decision is possible only in case of obligatory possession of theoretical knowledge in various areas of linguistics(Yusupova et al., 2014; Aminova et al., 2014; Mugtasimova et al., 2014; Nabiullina et al., 2014; Yusupova et al., 2013; Galiullina and Yusupova, 2014 and Denmukhametov and Denmukhametova, 2015).

\section{Literature Review}

As the outstanding Russian philologist of the XIX century wrote, the honorary member of many scientific academies of the world I. I. Sreznevsky, "the good dictionary has to satisfy each of those who resorts to it. Then the people are more educated, than more considerably in are mute the mass of the people educated that at it the dictionary of its language is better, richer, fuller, satisfactory" (Domestic lexicographers of the XVIII-XX century, 2000) that shows its mental qualities bringing to determination of identity of the people.

Ideally, each dictionary has to be embodied the main lexicographical principle - "the maximum of information in the minimum space without compromising the interests of the reader." The creation of such dictionaries, of course, assumes the mastery of special knowledge. The most basic thing in the bilingual dictionary compilation of accurate bills of 
equivalents (Berkov, 2004). At the same compilers and publishers of dictionaries should be aware that they contribute to better mutual understanding and co-operation between different nations.

In the history of Turkic lexicography Mahmoud's dictionary of Kashgaria (the XI century) of "Divanu lugat-at Turk" ("The dictionary of Turkic adverbs") in which the lexicon of Turkic tribes of Central Asia occurring during this period and partly the Volga region is recorded became sign (Hakov, 2003). There were also other Turkic dictionaries. For example, the dictionary called "Kitab-and Mediago tercuman Turks ve Ajami Mongol willow Farsi (General Ledger interpretations of the Turkic, Mongolian, and Persian languages"), based on Persian, Turkic, and Mongolian vocabulary. In 1875, Professor V. R. Rosen found the manuscript of this dictionary. P.M.Melioransky has carried out linguistic analysis of Turkic part of the manuscript. He adapted grammatical part of the dictionary for grammars of the European languages, and lexical material has placed based on the Arabic alphabet, having kept thus phonetic features of words. The author of the dictionary was not known, professor P.M.Melioransky in 1900 has published the manuscript under the name "The Arab Philologist about the Turkish Language" (Kononov, 1974). Subsequently the new copy of the manuscript has been found, and her author is established. The Arab philologist Ibn Mukhanna has appeared it. According to the famous linguist, the turcologist, S. E. Malov, the dictionary has been made at the end of XIII - the beginning of the XIV century.

The important place in the history of Turkic languages is taken "by the Code Kumanikus" - monument of Kipchak language of the end of XIII - the beginnings of the XIV century, made by Christian missionaries and repeatedly republished in the different countries. Colloquial Western Hunnish language of Turkic languages is reflected in the dictionary; Latin letters give glosses. The dictionary is important for studying the written language of the Turkic people developing at that time (Nadzhip, 1989 and Hakov, 2003).

One more valuable source for studying the history of Turkic languages has been made in 1313 by Abu-Hayan Garnati. Created in Cairo in the first half of the XIV century, i.e. in the period of the board in Egypt of Kypchak, the dictionary reflects the language of the mixed kypchaksko-oguzsky population of the state. The second edition of this work translated into the Turkish language by Professor A. Dzhaferoglu became the result of serious textual work (Nadzhip, 1989).

The special place among dictionaries is taken by "Kitab-i at-tuhfat uz-zakita fil-lugati it- turkita" ("Pleasant gift for studying of Turkic language"). This work has reached us in the single copy. For the first time, Professor M.F.Kepryulyuzade in one of the Hungarian magazines in 1922 has reported about it. Translation quality and the content of the lexical material of this dictionary is much higher than Abu-Hayan Garnati's dictionary. "Kitab-i at-tukhfat of bondszakita of fil-lugata IT tyurkita" has been published in Istanbul from an original photocopy, with translation and into the Turkish language. The dictionary totals 3000 units of which verbs make third. One more difference: Abu-Hayana Garnati's dictionary Arab-Turkic, and "Kitab-i at-tuhfat uz-zakita fil-lugati it-turkita" Turkic-Arab (Nadzhip, 1989).

The famous statesman and the outstanding scientist V. N. Tatishchev (1686-1750) who has made big contribution not only to development of philology, but also history, geography, ethnography and mining in Russia was the initiator and the active participant of drawing up number of Turkic dictionaries of other people. Being in 1737-1740 years the chief of the Orenburg expedition, has founded the Tatar-Kalmyk school at which, according to its instruction, began to translate books from east languages into Russian in Samara and have started drawing up the Tatar-Kalmyk dictionary (Tatar., 1999).

By V. N. Tatishchev's example, many have become interested in Russia in the lexical material. The empress Catherine II has charged to the chaplain of English trading station in St. Petersburg, to the honorary member of the Petersburg Academy of Sciences of D. Dyumaresku to make "The comparative dictionary of the East languages". As A. $\mathrm{N}$. Kononov writes, "this work was given character of the state enterprise" (lexical material gathered by parcel of questionnaires to the secular and spiritual administration), later scientists and in regions of the Russian Empire began to be engaged in systematization of lexical material and drawing up dictionaries. In 1785 under supervision of the bishop Damaskin the dictionary of languages of the different people, in the Nizhny Novgorod diocese living which has remained in the manuscript form, Russians, Tatars, Chuvashs, Mordva and Cheremis" has been presented ". Work is supplied with short historical, ethnographic, and statistical introduction (Kononov, 1974).

"The dictionary of the Chuvash language" that had included about 30000 words has been the same year finished anonymous hand-written. The "Russian-Kyrgyz dictionary" made "by the diligence of the major general and gentleman Skalon" (1774) has been probably connected with the project "Comparative Dictionary" also volume hand-written. In the linguistic collection of L. I. Bakmeyster, which has passed to F.P.Adelungu subsequently, there was also big Bashkir dictionary that has not reached us (Kononov, 1974).

The history and the theory of the edition of bilingual dictionaries still were not subject to monographic research in the Tatar linguistics. At the same time there is large number of the Tatar-Russian and Russian-Tatar dictionaries which are stored in Scientific Library of N. Lobachevsky of the Kazan Federal University, National RT library, in the Russian 
state library in the city of Moscow and in City library of the city of Berlin.

The worthy place in formation of the Tatar lexicography was taken by articles and the master's thesis of R. Nurmukhametova "The main tendencies of development of Lexicon of the Tatar literary language in the first half of the XX century (according to the Tatar-Russian dictionaries)" (Nurmukhametov, 2005; Nurmukhametova et al., 2014; Zamaletdinov et al., 2014). This first monographic research of the Tatar lexicon on materials of the Tatar-Russian dictionaries of the first half of the XX century - period of very intensive development of Lexicon of the Tatar literary language. The aspiration to synthesis in the Tatar language of all viable lexical means, irrespective of sources of their origin was the main tendency defining its development during this period. This tendency has found the fullest and bright reflection in the Tatar-Russian dictionaries.

Dictionaries of the Tatar language of the XIX-XX centuries is mentioned in works of V. N. Hangildina, L.Z.Zalyaya, R.S.Gazizova, F.S.Faseeva, G. S. Amirova, I.Sh.Avkhadiyeva, Sh.S.Khanbikovoy, V.Kh.Khakova, R.G.Akhmetyanova, M. G. Mukhamadiyeva, M.Z.Zakiyeva, F.M.Khisamovoy, E.N.Nadzhipa, F.A.Ganiyeva, F.S.Safiullinoy. Experience earlier Russian-foreign (German, English, French, etc.) dictionaries are reflected in these dictionaries. The Tatar-Russian and Russian-Tatar dictionaries of the XIX century have been investigated A.Sh.Yusupovoy as lexicographic sources of the Tatar language (Yusupova, 2008 and Yusupova, 2014). Noticed, that by originators of bilingual dictionaries of the Tatar language of the XIX century has put methodological and methodical traditions of the formation of the dictionary case of the XX century.

\section{Methods and Materials}

In modern linguistic studies of particular significance is the system approach. Before us is material in origin, content and purpose are so vast and diverse that without a systematic approach to identifying specific trends and patterns is simply impossible.

In addition, for the purpose of a comprehensive analysis of the vocabulary of the Tatar language in the XIX century according to the materials of the considered dictionaries used methods such as descriptive linguistic analysis of the objects of study in their diachronic and synchronic, comparative-historical method (includes system analysis vocabulary dictionaries by topic); historical-etymological (a comprehensive study of the origin and occurrence of lexical material, recorded in the bilingual dictionary of the Tatar language in the nineteenth century).The attempt of the use of elements of a statistical method for receiving quantitative indices, determination of the frequency of use and functional qualities, properties of the lexicon of dictionaries is made. By consideration of changes in the field of the borrowed lexicon during the different periods of the XIX century the comparative method was applied.

In the XIX century, studying of languages and life of the Turkic people has assumed in Russia still significant scale. New dictionaries in which Russian and another - language of one of the Turkic people living in Russia was one of the languages were created. The number of linguists-turcologists among whom there were great experts increased. For example, one of the most famous experts on such Turkic language as Chuvash, there was founder of domestic Chuvash linguistics, the author of capital works, the inspector of the Chuvash schools of the Kazan educational district, the graduate of philological faculty of the Kazan University N. N. Zolotnitsky. For 1871-1884 it has published 8 ChuvashRussian and Russian-Chuvash dictionaries, among them thematic work "Fragments from the Chuvash-Russian dictionary" (1871-1874) and "The root Chuvash-Russian dictionary compared to languages and adverbs of the different people Turkic, Finnish and others" (1875).

The significant contribution to studying of languages, ethnography and folklore of the Turkic people was brought by representatives of the Altai spiritual mission. Also, today have not lost the value the Altai-Russian dictionaries that have been published in 1868 - 1869.

Dictionaries Bashkir, Azerbaijani, Kyrgyz (Kazakh), Turkish, sartsky (Uzbek) languages were much less in comparison with Tatar-speaking dictionaries. In the XIX century, generally in its second half, only some such dictionaries that testify to the insignificant use of these languages in Russia during this period are published. Perhaps, it is possible to call only "The Turkish-Tatar-Russian dictionary with the application of short grammar" of L. Lazarev (1864) (under "Tatar" in this case the Azerbaijani language was meant).

Despite the fact that in the XIX century in the life of the East played the Turkish language large role, in Russia not so many the Turkish-Russian and Russian-Turkish dictionaries have been published. From their number it is possible to allocate the Russian-Turkish Dictionary of 1854 including 3000 lexical units (this work was the annex to grant for learning the Turkish language, written by A. M. Kazem-Bek), and L. Lazarev's dictionary mentioned above.

In the edition of the Bashkir bilingual dictionaries special role (1899) V. Katarinsky published in Orenburg have played "The desk Russian-Bashkir dictionary" (1893) and "The Bashkir-Russian dictionary". According to the Bashkir 
scientists, lexical units were reflected in them, characteristic for the dialects of the Bashkir language extended to territories of the Orenburg region (Kononov, 1974).

The Kyrgyz (Kazakh) bilingual dictionaries have been made in the conditions of completion of accession to Russia in the second half of the XIX century of Central Asia. Let's note "The Russian-Kyrgyz (Kazakh) and Kyrgyz-Russian dictionary" (1883) Ishmukhammad Bukin and "The desk Kyrgyz-Russian dictionary" (1895), "The Kyrgyz-Russian dictionary" (1897) and "The Russian-Kyrgyz dictionary" (1899-1900) V. V. Katarinsky. All dictionaries of the Inspector V. V. Katarinsky have been published by Missionary Society of the prelate Guriya (Kononov, 1974).

In the 80th years of the XIX century, grammars and dictionaries of the Uzbek language are created. So, in 1884 V.P. Nalivkin publishes the "Russian-Sart and the Sart-Russian dictionary of common words, with the application of short grammar on adverbs of the Namangan district". In 1895, there is "Pocket Russian-Uzbek dictionary..." S. Lapina.

Many principles developed by authors of bilingual dictionaries of the XIX century were widely used in Turkic lexicography of the XX century.

The Tatar bilingual lexicography traces the roots back to XVI-XVII of the eyelid. Throughout this period, it has been made some Russian-Tatar hand-written dictionaries intending for the different purposes. Long before it among merchants there were in the use small hand-written phrasebooks and pocket dictionaries which necessity has been caused by the life (Nogman, 1969). These constantly being replenished books have served as prototypes for the creation of new dictionaries.

From the second half of the XVIII century in Russia, there are dictionaries of the Turkish language, rather big on volume, in translation into the French, English and German languages. Then the hand-written Russian-Tatar dictionary of S. Halfin (1785) containing about 25000 words has been prepared. In the preface of his work the author wrote: "... Because until now Tatar dictionary for add-on business with the people needs are not yet, I am having a directorate of Kazan gymnasium gladly taken on the composition of Nago also briefly Tatar grammar ...".Words in the dictionary are located in three columns: the first included the Russian words, in the second the Russian transcription of the Tatar words, in the third - the Tatar words in the Arab graphics is given (Nogman, 1969).

It should be noted that separate plots of this subject appeared in sight of the Tatar researchers. M. Nogman made the big contribution to studying of hand-written bilingual dictionaries of the Tatar language. In 1964 M. Nogman has defended the master's thesis "The Russian-Tatar hand-written dictionaries XVII - the XVIII centuries" based on which in 1969 he has published the monograph. The hand-written Russian-Tatar dictionaries XVII considered by it - have been found the XVIII centuries by the author in hand-written funds of archives of St. Petersburg, Moscow, and Kazan. In its historical conditions of the creation of the Russian-Tatar hand-written dictionaries are analyzed, the lexicon of 11 dictionaries taking into account various dialects and dialects of the Tatar language is in detail lit. M. Nogman's works have made a big contribution to studying the history of the Tatar language.

In this work classification of bilingual dictionaries by input language, i.e. by language from which transfer is made is offered. The first group - group of the Tatar-Russian dictionaries - words radical, the most necessary note for training in the Tatar language, collected at the Tobolsk main school by the teacher of the Tatar language, St. Sophia Cathedral priest Iosif Giganov and Yurt mullahs testified" make I. Giganov's work published in St. Petersburg 1801godu in publishing house of Imperial Academy of Sciences, "; A.Troyansky "Dictionary Tatar language commonly used in it some Arabic and Persian sayings collected works of a teacher of the Tatar language at the Kazan seminary priest Alexander Trojan and printed with the permission of the commission of religious schools", published in printing house of the Kazan university in 1833; "Dictionary of the Tatar anthology" Salikhzhana Kuklyasheva, published in the same printing house in 1859 year; "The unabridged Russian-Tatar dictionary with addition from the foreign word used in Russian as scientific terms" the prominent Tatar educator K. Nasyri, published in 1892 year in publishing house of the bookseller Fatkhulla Amashov in the city Kazan; also "The comparative dictionary of the Turkish-Tatar adverbs with inclusion of the most common words Arab and Persian and with translation into Russian" L. Budagova, published in St. Petersburg in printing house of Academy of Sciences in 1869; "Translation with Tatar into Russian language or the dictionary" Sh. Gabdelgaziza, published in the Kazan University Tipo-lithography in 1893; N. Ostroumov's dictionaries "First experiment of the dictionary of the national-Tatar language on reprimand of baptized Tatars of the Kazan province", published in printing house of the Kazan University in 1876godu, and the "Tatar-Russian Dictionary" published by Orthodox missionary society in Kazan 1892, and "The Tatar-Russian dictionary of the most common words and expressions" M. Yunusova, published in printing house of Trading House of Brothers Kasimov in the city Kazan in 1900 year. In these dictionaries, input language is Tatar, day off - Russian. These dictionaries for the Russian user were passive, because they have been intended for reading texts in the Tatar language, for translation of the Tatar texts into Russian, and for storing of the Tatar words. In them, words, active in the informal Tatar conversation, generally belonging to the subject of life, clothes and food, environment have been pledged. However using the same dictionaries the Tatar speaking user 
could translate words, texts from the mother tongue into Russian, and for it they were active.

It should also be noted that fact that the lexicon is reflected in dictionaries in N. Ostroumov's dictionaries the Tatar Kryashen (Tatars with orthodox religion) which is active and to this day. Moreover, in K. Nasyri and Sh. Gabdelgaziz's dictionary it is possible to see also lexicon with Muslim subject though on it the emphasis especially was not placed.

There were also such lexicographic sources as "The dictionary Russian-Tatar, collected in Tobolsk the main national school by the teacher of the Tatar language I. Giganew and mullahs Yurt", published in St. Petersburg 1804 in publishing house of Imperial Academy; The "Tatar-Russian dictionary" of K. Nasyri published in printing house of the Kazan imperial university in 1878, and "The Russian-Tatar dictionary with the preface about pronunciation and etymological changes of the Tatar words of A. Voskresensky", published in the same printing house in 1894 are RussianTatar, i.e. input language of these dictionaries is Russian, and they make the second group. These dictionaries reflect, generally the general lexicon: verbs of motion, seasons and natural phenomena, names of furniture, etc.

The Tatar-Russian and Russian-Tatar dictionaries of eyelid also differ in structure. The ratio of parts of the dictionary and the principles of its organization is called as structure. Distinguish some types of structures of dictionaries: megastructure, or frame structure - interposition of parts of the dictionary (the preceding text, the case concluding the text); macrostructure, or order of arrangement of words in the dictionary (Berkov, 2004). The macrostructure of the studied dictionaries is divided into alphabetical and thematic. Refer to alphabetical dictionaries I. Giganova (1804), A. Trojansky $(1833,1835)$, S. Kuklachev (1859), K. Nasyri $(1878,1892)$, L. Budagov $(1869,1871)$, N. Ostroumova (1876, 1892), M. Yunusova (1900). The thematic dictionaries with systematic microstructure are dictionaries of I. Giganova (1801) and Sh. Abdelaziz (1893).

It should be noted that the Tatar-Russian dictionaries of the XIX century were passive, i.e. were addressed to Russian-speaking pupils, many of them have been intended more for reading texts in the Tatar language. Users could find in them, first of all, translation equivalents.

\section{Results and Discussions}

In the ideal, the dictionary has to be intended to one addressee. The Tatar-Russian dictionaries of the XIX century are addressed to Russian-speaking users they are mono-directional. At the same time at them, there is material acquainting with history, traditions, folklore of the Tatar people, data on the phonetic and grammatical system of the Tatar language contain.

\section{References}

Berkov, V.P. (1971). Questions of bilingual lexicography, Leningrad University of A.A. Zhdanov. Leningrad. pp. 30.

Canons, A.N. (1974) Bio bibliographic dictionary of domestic turcologists (pre-October period). Moscow. Science. pp. 340.

Nadzhip, E.N. (1989) Research on the history of the Turkic XI-XIV languages of centuries Moscow: Science. pp. 291.

Nogman, M. (1969) Russian-Tatar handwritten dictionaries XVП-XVШ centuries Kazan: Publishing house Kazansk. the state university. pp 112.

Domestic lexicographers of XVIII-Hkhveka (2000). Moscow: Science. pp. 508.

Tatar encyclopedic dictionary (1999). Kazan: Institute of the Tatar encyclopedia of AN of RT. pp. 703.

Khakov, V.Hh. (2003). Language- Mirror stories. Kazan: Eeducation. pp 295.

Nurmukhametova, R.S., (2005) Main tendencies of development of lexicon of the Tatar literary language of the first half of the XX century: according to the Tatar-Russian dictionaries: Thesis of Candidate of Philology. Kazan, pp. 258.

Yusupova, A.Sh., (2008) Bilingual lexicography of the Tatar language of the XIX century. Kazan: Publishing house Kazansk. the state university. pp. 410.

Yusupova, A.S., Galiullina G.R. \& Denmukhametova E.N. Representation of national mentality in Turkic-Tatar vocabulary. Life Sci J 2014;11(7):506-508] (ISSN:1097-8135). http://www.lifesciencesite.com. 66.

Aminova, A.A., Gilazetdinova G.Kh. \& Edikhanov I.Zh. (2014) Problems of Ethnocultural Identity and Cross-Language Communication /I Journal of Language and Literature. 5(3), 39-42.

Zamaletdinov, R.R. (2014) The lexicon and its reflection in the inner world of the individual (on the basis of the Tatar language) / G.F. Zamaletdinova, R.S. Nurmukhametova, M.R. Sattarova // Journal of Language and Literature. 5(4), 333-335.

Mugtasimova, G.R., Nabiullina G.A. \& Denmukhametova E.N. (2014) Paremiological Fund of the Tatar people in the ethno-linguistic aspect. Life Sci J; 11(11):409-412. http://www.lifesciencesite.com. 69

Nabiullina, G.A., Denmukhametova E.N. \& Mugtasimova G.R. (2014) The linguistic characteristics of Tatar Paroemiae. Life Sci J; 11(5):559- 562 (ISSN: 1097-8135). http://www.lifesciencesite.com. 85

Yusupova, A.S, Denmukhametova I.N., Nabiullina G.A. \& Mugtasimova G.R. (2013) Features of the Language of Tatars Living in China // Middle-East Journal of Scientific Research 17 (2): 168-172. IDOSI Publications. DOI: 10.5829/idosi.mejsr.2013.17.02.12181. 
Galiullina, G.R. \& Yusupova A.S. (2014) European linguistic borrowings in the Tatar sprachraum (by written sources of the XIX-XX centures). Life Sci J. 11(10):697-700. http://www.lifesciencesite.com. 110.

Yusupova, A.S (2014).Russian-Tatar dictionaries of the first half of the 19th century//Journal "Tatarica" / № 3. s.29-47

Nurmukhametova, R.S. (2014) The vocabulary of Tatar literary language (the first half of the XX century) / Nurmukhametova R.S., Zamaletdinov R.R. and Sattarova M.R. // Life Science Journal. 11(10) pp. 670-673 http://www.lifesciencesite.com

Denmukhametov, R.R. \& Denmukhametova E.N. (2015) Geographical Terms and Concepts as the Evidence of Material and Spiritual Culture of the Tatar Language//Mediterranean Journal of Social Sciences. 2015. Vol 6, No3, May 2015. - pp.:777-780. Doi:10.5901/mjss.2015.v6n3p777. 